\title{
The Effects of Facebook on Students' Social Life: A Case Study at Mirwais Khan Nika Zabul Institute of Higher Education, Zabul
}

\author{
Abdul Nafi Himat \\ English Language and Literature Department \\ Education Faculty, Kandahar University, Kandahar, Afghanistan \\ E-mail: abdulnafi.himat2017@gmail.com
}

Received: May 05, 2020

Accepted: May 25, 2020

Online Published: June 06, 2020

doi: 10.46281 /aijssr.v5i3.593

URL: https://doi.org/I0.4628I/aijssr.v5i3.593

\begin{abstract}
In the world, Facebook is one of the most well-known social networking sites, which is used a lot among students. The purpose of this research is to identify the devoted time students' spend on the usage of Facebook, and its impacts on learners' social life at Mirwais Khan Nika Zabul Institute of Higher Education, Zabul, Afghanistan. In this study, the quantitative research method was used to collect data from one hundred and fifteen students, and they were selected through a random sample. Likewise, the questionnaire was designed based on the literature review then the data was collected from the participants. Similarly, the data was analyzed by using IBM 24 version of SPSS and found out the frequency and percentage of the demographic data as well as the items. Also, the findings of this research illustrate that learners were devoted from half to one-hour time for using Facebook. Moreover, the results assert that learners want to maintain in connection with people, feel fine when they share their ideas on Facebook and it had positive effects on students' social life.
\end{abstract}

Keywords: Facebook, Devoted Time, Effects, Social Life, Students

\section{Introduction}

In recent decades, many people who live in Afghanistan have access to technology and get benefits from it, especially students who study in universities and higher education institutions. Likewise, technology brought many changes in the life of humans in Afghanistan; therefore, it has received a considerable attention of them. In general, technology has replaced the way people interact and allows the inhabitants of the earth to connect with each other, and make the world as a global village (Boateng \& Amankwaa, 2016; Chowdhury \& Saha, 2015). Likewise, the rapid progress of information and communication technologies has brought modifications in several educational and technological applications and processes (Lenhart \& Madden, 2007; Selwyn, 2007). Moreover, this century is known as a digital age, computer and internet have gained an absolutely central importance in the life of humans (Kirik, Arslan, Cetinkaya \& Mehmet, 2015). Furthermore, internet attract all people because it provides new ways for communication with other people (Heiberger \& Harper, 2008).

Likewise, from the beginning of the $2 \mathrm{I}^{\text {st }}$ century, social media is in progress, and it plays a vital role in life because people belonging to different age groups use social media. In addition, social media websites have become common, and they give young people a new way to interact with each other, also an opportunity to communicate with the world (Schneider, 2010). As well as, social media has a prominent role in the life of humans, and the development of communication network is one of the factors that lead individuals to use social media (Kirik et al., 2015). Furthermore, social media change quickly the communication setting of today's social world as well as it helps individual to share connections, views, thoughts with unknown friends or enable to share their view points with visible well-known friends (Paul, 2017; Boateng et al., 2016; Chowdhury et al., 2015).

Moreover, the use of social media is being quickly rising during the last few years. It is not only being used by the working people, but also there is a heavy increase in the use of social media by the students (Sangwaan, 2019). Therefore, it has become an indispensable part of the communication age (Aygul, 2010). In addition, Facebook is very common between college learners, even though they use it when they have classes, likewise; Facebook is the most used social network sites by college students (Wang, Chen \& Liang, 20II). Additionally, the term social media is a collection of applications, namely, Facebook, Twitter, 
WhatsApp, YouTube, Instagram, Flickr, YouTube, LinkedIn and so on, and these social networking sites connect people to share details and alert individuals about any event in the community (Ali, Iqbal \& Iqbal, 20I6).

Similarly, on social media Facebook is one of the most heavily social networking sites in all over the world, and through the usage of this users can express their selves freely, establish new friendships, relationships, and follow their friends. Moreover, they can engage in dialogues with people or groups they are interested in (Aygul, 2010). In Facebook users can register their selves in an account, and can post material about their life also they can create a profile to upload details about their selves and add other consumers as friends. As well as, once registered, they can exchange messages with one others, post updates, share photos and videos as well they can also join with others to form groups (Mason, 2017). Therefore, Facebook is the biggest social network sites in the world. In addition, in December 2012, it had one billion monthly active users, and the implementation of Facebook between pupils increased over time; similarly, it was founded in $4^{\text {th }}$, February, 2004 by Mark Zuckerberg (Gafni \& Deri, 20I2; Kirkpatrick, 2010; Ellison, Steinfield \& Lampe, 2007). Likewise, at first, the usage of Facebook was limited for students in Harvard University, but afterwards, it became accessible to all over the world; similarly, it became the largest social network worldwide as well it is now the biggest social networking services based on total active users and its universal reach to everyone (Kirkpatrick, 2010; Ellison et al., 2007).

\section{I.I Problem Statement}

In recent years, students who have access to internet spend most of their time on social media, especially on Facebook. In Afghanistan, users of social media limited their usage to a few platforms, namely Facebook and instant messaging platforms (Altai Consulting for Interviews, 2017). Therefore, students who study at Mirwais Khan Nika Zabul Institute of Higher Education, Education Faculty devoted most of their time for using Facebook as a social networking site. This problem was also existed in South Africa and Ghana as well as in Botswana University (Eke, Omekwu \& Jennifer, 20I4; Diraditsile \& Gamakabadi, 20I8). According to Wang et al., (20II) many parents of learners are worried about their college students because they spend so much time on social media networking sites, especially on Facebook and do not devote enough time for their study. Moreover, this phenomenon is an international concern that about $99 \%$ of students in America use social networking sites and the time they spend is frightening (Johnson, 2013). Moreover, there are very limited studies conducted at Mirwais Khan Nika Zabul Institute of Higher Education, Zabul, Afghanistan. As Facebook is the most famous social networking site. Consequently, this study would assist with students who study in universities, higher education institutions and with the Ministry of Information and Communications Technology of Afghanistan.

\section{I.2 Objectives of the Research}

- To identify the devoted time students', spend on the usage of Facebook at Mirwais Khan Nika Zabul Institute of Higher Education.

- To investigate the impacts of Facebook on learners' social life at Mirwais Khan Nika Zabul Institute of Higher Education.

\section{I.3. Research Questions}

- How much time students' devoted for the usage to spend on Facebook at Mirwais Khan Nika Zabul Institute of Higher Education?

- What are the impacts of Facebook on students' social life at Mirwais Khan Nika Zabul Institute of Higher Education?

\section{Literature Review \\ 2.I Devoted Time Students Spend on Facebook}

Facebook is almost universally-used among higher education learners, and they consider Facebook as their main social media choice, thus spend a great part of their time on its use on their normal day (Ellefsen, 20I6). Moreover, Nawafleh, Harfoush, Fakhouri, Obiedat \& Rababah, (2012) wanted to find the negative effects of Facebook on user social life in Amman. The findings of this study asserted that $49 \%$ Facebook users used it more than three hours a day, $72 \%$ used several hours a day, and they couldn't reduce the using hours. Additionally, students spend a considerable amount of time actively on Facebook. In addition, the study of Ellison et al., (2007) showed that college students use Facebook on an average of I0 to 30 minutes daily. Similarly, Pempek, Yermolayeva \& Calvert, (2009) study revealed that college students spend an average of 27.93 minutes per day during weekdays and an average of 28.44 minutes per day during weekends on Facebook. Also, social networks (Facebook in particular) was a part of their daily life. Moreover, Alhazmi \& Rahman, (2013) reported that $78.9 \%$ of students spend more than one hour a day on Facebook.

\subsection{Impacts of Facebook on Students' Social Life}

A qualitative case study by Akbiyik (2013) in Turkey, to determine the effects of social networks on college undergraduate students' social life. The findings of this study revealed that the use of Facebook helps users to communicate with their friends, 
and it assists with the consumers to know and learn about their friends. Similarly, pictures or videos shared in the Facebook environment by students aid them to start conversation, thus it makes communication easier. This way of communication is realized by liking or disliking the posts or by making comments on the shared objects. The findings also asserted that Facebook also has negative impacts on students because most of them complain about maintaining reconnection with old friends does not make them contend in cases where lifestyles have differentiated. They stated more that they couldn't feel the same old intimacy once lifestyles have changed. As well as, it was annoying for students when their relatives try to control their Facebook behaviors. The findings showed that they get friendship requests from people whom they do not like to meet in their real life. Also, students stated that some of their classmates do not talk them in a real life but add them as Facebook friends. Three learners stated that they could not trust relationships or conversations in the Facebook environment because this environment is virtual. The findings more disclosed that pupils think even though they know the person in real life, they cannot be certain if he is telling the truth when they communicate with him in the virtual environment. Furthermore, expressing political views on the Facebook environment has a negative effect on learners' social life and relatives were not desired as Facebook friends by some of the participants.

Similarly, research by Nawafleh et al., (2012) wanted to find the negative effects of Facebook on user social life in Amman. Their findings asserted that Facebook is a well-known website that connects people, socialize, make a connection with famous people, make new friends, and build up new relationships. Furthermore, the findings of the study indicated that Facebook has negative impacts on users' social life. Moreover, research conducted by Tang-Mui \& Teng, (2017) findings demonstrate that Facebook is the main source of information from personal to global news without verifying its trustworthiness. Facebook is used as a tool to communicate with friends and family. Facebook has perceived as a good tool of communication that can bring closeness among the family members. The use of Facebook brings positive impact towards family members, with the continuously increasing number of local Facebook users, and it will help to build a better and harmonic society. Through the use of Facebook, the relationships between family members and communication will be improved and enhanced the level of a united community.

Likewise, a case study carried out by Chowdhury et al., (2015) on the impact of Facebook on youth generations in Kolkata, India. The positive effects asserted that Facebook allow all teenagers as well as Facebook users to communicate with their friends. Moreover, learners can build relations with known and unknown friends. Also, users can maintain their past and new bonding of friendship and other relations. Facebook connect students with different cultures, religions. In addition, findings revealed that Facebook increases empathy for their existing and old friends, which gives more systematic communications. Similarly, the negative impacts showed that most of the users only use Facebook to check their profile or any new update posted on their wall. Additionally, the results showed that chatting with friends reduces the importance of writing letters and face to face human contacts. The study further stated that several photos, videos or political shares divert their attention. Mustafa \& Hamzah, (20I I) study asserted that Facebook is used for communication with other friends and as a way to reconnect them to their old friends. Furthermore, Facebook improves family communication as it provides a platform for Malaysians to discuss issues that they never talk face-to-face. It also had effects on their relationships within the family and between generations. Moreover, Salvation $\&$ Adzharuddin, (20I4) findings revealed that social media had become the most active application which assists students not only to socialize with friends as well as to interact with lecturers.

\section{Research Methodology \\ 3.I Research Design}

This study investigated the impacts of Facebook on students' social life at Mirwais Khan Nika Zabul Institute of Higher Education, Qalat, Zabul, Afghanistan. A quantitative research method was used for this study. According to Aliaga \& Gunderson (2002) in a quantitative research approach, the researcher is describing a topic through getting data in a numerical form and analyzing it with the assist of the mathematical method. This study was based on the strategy of a case study because most scholars agree that it is a strategy, but not a particular method (Yin, 1994). Additionally, in a case study the researcher(s) tries/try to find responses for 'what', 'why', and 'which' and it refers to research that investigate a few cases in considerable depth which is known a case study (Yin, 1994; Gomm, Hammersley \& Foster, 2000).

\subsection{Population and Sampling}

In this research, the participants were from Mathematics, Biology, Chemistry, and Physics Departments, Education Faculty. Similarly, the sample size was (II5) learners', and they were from all the existed three educational levels freshmen, sophomore, and junior as well as they were selected through random sampling method. In a random sample the participants are the representative of a larger group.

\subsection{Research Instrument}

In this study, the data was collected through a questionnaire, and it had three parts, the demographic data of the respondents, the devoted time students' spend on the usage of Facebook (5 items), and the impacts of Facebook on students' social life (7 items). 


\subsection{Validity and Reliability of the Questionnaire}

The questionnaire was checked several times, and after receiving comments, it had revised. According to Madan \& Kensinger (2017) the reliability value among .75 and I.00 is considered excellent. Likewise, the reliability of the current study's instrument was checked and it was 86 Cronbach's Alpha, which is considered excellent.

\subsection{Data Analysis Procedure}

The data was analyzed by using IBM 24 version of Statistical Package for the Social Sciences (SPSS), and found out the frequency and percentage as well as reported in tables.

\section{Findings}

The findings of the study asserted the demographic data, devoted time students' spend on Facebook, and its impacts on students' social life.

Table I. Shows the demographic data of the participants

\begin{tabular}{|c|c|c|c|}
\hline \multicolumn{4}{|c|}{ Demographic Data of the Respondents } \\
\hline & Characteristics & Frequency & Percentage \\
\hline \multirow[b]{2}{*}{ Gender: } & Male & I I2 & 97.4 \\
\hline & Female & 3 & 2.6 \\
\hline \multirow[t]{3}{*}{ Level of Education: } & Freshmen & 38 & 33.0 \\
\hline & Sophomore & 30 & 26.1 \\
\hline & Junior & 47 & 40.9 \\
\hline \multirow[t]{4}{*}{ Age: } & 18 years & 20 & 17.4 \\
\hline & Between $19 \& 25$ & 87 & 75.7 \\
\hline & Upper 25 & 4 & 3.5 \\
\hline & Upper 27 & 4 & 3.5 \\
\hline \multirow{4}{*}{$\begin{array}{l}\text { Departments of Education } \\
\text { Faculty: }\end{array}$} & Biology & $4 \mathrm{I}$ & 35.7 \\
\hline & Chemistry & 28 & 24.3 \\
\hline & Mathematics & 25 & 21.7 \\
\hline & Physics & $2 \mathrm{I}$ & 18.3 \\
\hline
\end{tabular}

Table I. shows the demographic data of the participants in categories of gender, level of education, age, and Education Faculty's Departments. In this study, I I5 students participated which many learners were male (97.7\%), and surprisingly (2.6\%) were female. In addition, (33\%) freshmen, (26.1\%) sophomore, and (40.9) are junior. Similarly, about to the age (I7.4\%) I8 years old, (75.7\%) between 19 and 25, (3.5\%) upper 25, and (3.5\%) are upper 27 years old. Moreover, (35.7\%) from Biology, (24.3\%) Chemistry, (21.7\%) Mathematics and (I8.3) are from Physics Departments.

Research Question I. How much time students devoted for the usage to spend on Facebook at Mirwais Khan Nika Zabul Institute of Higher Education?

Table 2. Show the time students devoted for the usage of Facebook.

Table 2.I more than three hours

\begin{tabular}{lcc}
\hline & Frequency & Percentage \\
\hline Never & $7 \mathrm{I}$ & 61.7 \\
\hline Rarely & 8 & 7.0 \\
\hline Sometimes & 15 & 13.0 \\
\hline Often & $\mathrm{I} 3$ & $\mathrm{II.3}$ \\
\hline Always & 8 & 7.0 \\
\hline Total & $\mathrm{II}$ & $\mathrm{I} 00.0$ \\
\hline
\end{tabular}


Table 2.1 asserts $61.7 \%$ never devote time more than three hours in a day, 7\% rarely, I3\% sometimes, II.3 often while less amount 7\% of learners devote more than three hours for using Facebook.

Table 2.2 three hours

\begin{tabular}{lcc}
\hline & Frequency & Percentage \\
\hline Never & 58 & 50.4 \\
\hline Rarely & $\mathrm{I} 8$ & $\mathrm{I}$ \\
\hline Sometimes & 20 & $\mathrm{I} .7$ \\
\hline Often & $\mathrm{I3}$ & $\mathrm{I}$ \\
\hline Always & 6 & $\mathrm{II}, 3$ \\
\hline Total & $\mathrm{II} 15$ & 5.2 \\
\hline
\end{tabular}

Table 2.2 illustrates $50.4 \%$ of students never devote three hours for Facebook, I5.7\% rarely, I7.4 sometimes, II.3\% often. In addition, very less amount of learners 5.2\%, devote three hours for Facebook.

Table 2.3 two hours

\begin{tabular}{lcc}
\hline & Frequency & Percentage \\
\hline Never & 47 & 40.9 \\
\hline Rarely & 16 & 13.9 \\
\hline Sometimes & 20 & 17.4 \\
\hline Often & 24 & 20.9 \\
\hline Always & 8 & 7.0 \\
\hline Total & II5 & 100.0 \\
\hline
\end{tabular}

Table 2.3 reveals $40.9 \%$ never devote time two hours, $13.9 \%$ rarely, $17.4 \%$ sometimes, $20.9 \%$ often while less amount of learners $7 \%$ devote for Facebook.

Table 2.4 one hour

\begin{tabular}{ccc}
\hline & Frequency & Percentage \\
\hline Never & I7 & I4.8 \\
\hline Rarely & I9 & I6.5 \\
\hline Sometimes & 24 & 20.9 \\
\hline Often & 34 & 29.6 \\
\hline Always & 21 & 18.3 \\
\hline Total & II5 & 100.0 \\
\hline
\end{tabular}

Table 2.4 highlights I4.8\% devote time one hour, I6.5\% rarely, 20.9\% sometimes, less than half of the participants often use $29.6 \%$ while $18.3 \%$ always.

Table 2.5 less than one hour

\begin{tabular}{|c|c|c|}
\hline & Frequency & Percentage \\
\hline Never & 9 & 7.8 \\
\hline Rarely & 23 & 20.0 \\
\hline Sometimes & 31 & 27.0 \\
\hline Often & 28 & 24.0 \\
\hline Always & 24 & 20.9 \\
\hline Total & II5 & 100.0 \\
\hline
\end{tabular}

Table 2.5 asserts very a smaller number of students $7.8 \%$ never devote time less than one hour for Facebook, 20\% rarely, $27 \%$ sometimes, $24 \%$ often while $20.9 \%$ always devote their time. 
Research Question 2. What are the impacts of Facebook on students' social life at Mirwais Khan Nika Zabul Institute of Higher Education?

Table 3. show the impacts of Facebook on students' social life

Table 3. I like to have friends from my relatives on Facebook

\begin{tabular}{ccc}
\hline & Frequency & Percentage \\
\hline Strongly Disagree & 9 & 7.8 \\
\hline Disagree & 5 & 4.3 \\
\hline Somehow Agree & 19 & 16.5 \\
\hline Agree & 28 & 24.3 \\
\hline Strongly Agree & 54 & 47.0 \\
\hline Total & 115 & 100.0 \\
\hline
\end{tabular}

Table 3.I demonstrates that $7.8 \%$ of students are strongly disagree because they do not like to have friends on Facebook from their relatives, very less $4.3 \%$ of learners disagree, 16.5\% somehow agree, $24.3 \%$ agree, but a large number of students are $47 \%$ strongly agree.

Table. 3.2 Facebook helps me to maintain in connections with people whom I cannot see them in real life

\begin{tabular}{ccc}
\hline & Frequency & Percentage \\
\hline Strongly Disagree & 9 & 7.8 \\
\hline Disagree & 4 & 3.5 \\
\hline Somehow Agree & 19 & 16.5 \\
\hline Agree & 34 & 29.6 \\
\hline Strongly Agree & 49 & 42.6 \\
\hline Total & 115 & 100.0 \\
\hline
\end{tabular}

Table 3.2 indicates $7.8 \%$ are strongly disagree because the students reported that Facebook does not assist them in maintaining connections with persons whom they cannot see them in their real life; fewer amount of students $3.5 \%$ are disagreed as well as I6.5\% somehow agrees. In addition, $29.6 \%$ agrees with the mentioned item, and $42.6 \%$ are strongly agreed.

Table. 3.3 I feel good when sharing my opinions on Facebook

\begin{tabular}{ccc}
\hline & Frequency & Percentage \\
\hline Strongly Disagree & I0 & 8.8 \\
\hline Disagree & 4 & 3.5 \\
\hline Somehow Agree & 23 & 20.2 \\
\hline Agree & 42 & 36.6 \\
\hline Strongly Agree & 36 & 31.6 \\
\hline Total & II5 & I00.0 \\
\hline
\end{tabular}

Table 3.3 reveals $8.8 \%$ strongly agree because the students do not feel good when they share ideas, very less amount disagree 3.5 , and $20.2 \%$ are somehow agrees. Moreover, $36 \%$ agree, and $31 \%$ strongly agrees with.

Table. 3.4 Facebook has effects on my social life

\begin{tabular}{|c|c|c|}
\hline & Frequency & Percentage \\
\hline Strongly Disagree & II & 9.6 \\
\hline Disagree & 7 & 6.1 \\
\hline Somehow Agree & 17 & I4.8 \\
\hline Agree & 40 & 34.8 \\
\hline Strongly Agree & 40 & 34.8 \\
\hline Total & II5 & 100.0 \\
\hline
\end{tabular}


Table 3.4 shows $9.6 \%$ reported that Facebook does not have any impacts on our social life. Similarly, 6.I\% are disagreed, and $14.8 \%$ are somehow agree. Furthermore, $34.8 \%$ are agree and strongly agree.

Table. 3.5 When I share photos on Facebook, it assists me to communicate with my friends especially when he/she likes/dislikes or share

\begin{tabular}{ccc}
\hline & Frequency & Percentage \\
\hline Strongly Disagree & $\mathrm{I} 2$ & $\mathrm{I}$ \\
\hline Disagree & $\mathrm{I} 3$ & $\mathrm{II} .3$ \\
\hline Somehow Agree & 25 & 21.7 \\
\hline Agree & 40 & 34.8 \\
\hline Strongly Agree & 25 & 21.7 \\
\hline Total & $\mathrm{II5}$ & $\mathrm{I}$ \\
\hline
\end{tabular}

Table 3.5 demonstrates I0.4\% are strongly disagree, I I.3\% disagrees. In contrast, $21.7 \%$ are somehow agree, $34.8 \%$ of the students are agree because they reported that it is good to communicate with friends when they like/dislike our posted images, and $21.7 \%$ strongly agrees.

Table. 3.6 I believe in the relationships of my friends on Facebook

\begin{tabular}{|c|c|c|}
\hline & Frequency & Percentage \\
\hline Strongly Disagree & $\mathrm{I} 4$ & 12.2 \\
\hline Disagree & 13 & II.3 \\
\hline Somehow Agree & 38 & 33.0 \\
\hline Agree & 33 & 28.7 \\
\hline Strongly Agree & 17 & $\mathrm{I} 4.8$ \\
\hline Total & II5 & 100.0 \\
\hline
\end{tabular}

Table 3.6 asserts $12.2 \%$ of students do not believe on the relations of their friends in Facebook, II.3\% disagrees. However, 33\% somehow agrees. Furthermore, 28.7\% are agreed, and I4.8\% strongly agrees.

Table. 3.7 Through Facebook I can connect with my friends

\begin{tabular}{ccc}
\hline & Frequency & Percentage \\
\hline Strongly Disagree & I3 & II.3 \\
\hline Disagree & II & 9.6 \\
\hline Somehow Agree & 24 & 20.9 \\
\hline Agree & 30 & 26.1 \\
\hline Strongly Agree & 37 & 32.2 \\
\hline Total & II5 & I00.0 \\
\hline
\end{tabular}

Table 3.7 highlights II.3\% of the students reported that we couldn't join with our friends On Facebook while $9.6 \%$ disagrees. Likewise, $20.9 \%$ somehow agreed, $26.1 \%$ are agreed, and $32.2 \%$ of the participants are strongly agreed.

\section{Discussion}

\section{I Devoted Time of Students' for Facebook at Miwais Khan Nika Zabul Institute of Higher Education}

The findings of this current research demonstrate that students do not use Facebook more than three hours a day, but very less amount of them use it. Furthermore, learners do not use Facebook for three hours, but 5.2\% always use three hours. It means that students do not want to waste their time on the use of Facebook; therefore, they do not allocate much time for Facebook. This finding is not in accordance with Ellefsen (2016) that Facebook is almost universally-used among higher education pupils, and they consider Facebook as their main social media choices, thus spend a great part of their time on its use in their normal day as well as with Nawafleh et al., (2012) wanted to find the negative effects of Facebook on user social life. Their findings asserted that $49 \%$ of Facebook users used it more than three hours a day, $72 \%$ used Facebook several hours a day and they couldn't reduce the using hours. Students, on the other hand, spend a considerable amount of time actively on Facebook. This finding is only in 
line with this study that college learners use Facebook on an average from I0-30 minutes daily (Ellison et al., 2007) because students who study at Mirwais Khan Nika Zabul Institute of Higher Education do not devote much time for the implementation of Facebook.

According to O'Keeffe \& Clark-Pearson (20I I) that the American Academy of Pediatrics (AAP) classified the time spend on social media into three categories as a high (more than 2 hours), average (30 minutes to 2 hours) and low use (less than 30 minutes). Additionally, the finding of this study indicates that students of Mirwais Khan Nika Zabul Institute of Higher Education, Education Faculty, do not use Facebook two hours, but fewer learners use it. Through these findings, it can be said that students devoted time approximately from half-hour to an hour in a day, which is considered as an average use. This finding is in line with Pempek et al., (2009) study revealed that college students spend an average of 27.93 minutes per day during weekdays and an average of 28.44 minutes per day during weekends on Facebook. In addition, social networks, especially Facebook, was a part of their daily life. Moreover, these studies are in line with that students primarily spend between 10 and 60 minutes on Facebook per day (Orr, Sisic, Ross, Simmering, Arseneault, \& Orr, 2009; Sheldon, 2008; Stern \& Taylor, 2007; Valenzuela, Park, \& Kee, 2009). However, the finding of Alhazmi et al., (2013) is against with that 78.9\% of students spend more than one hour a day on Facebook.

\subsection{Impacts of Facebook on Students' Social Life at Mirwais Khan Nika Zabul Institute of Higher Education}

The result of this study reveals that students like friends from their relatives on Facebook. From this finding, it can be said that students like to have relationship as well interaction among their folks because social media, especially Facebook, is one the communication tool that makes communication easier between friends. This finding is in consistent with the researchers Nawafleh et al., (2012) to find the negative effects of Facebook on social life in Amman, Irbid, and Jaresh cities. Their study asserted, that Facebook is a part of their everyday activity and can't leave it, $45 \%$ preferred to communicate with their friends and relatives through Facebook rather than direct interaction because they valued indirect interaction, 27\% Facebook causes loss of direct communication or face-to-face meeting with relatives and friends. As well as, this finding is not in match with a qualitative study carried out in Turkey to determine the effects of social networks on college undergraduate students' social life that expressing political views on the Facebook environment has negative effects on learners' social life and relatives were not desired as Facebook friends by some of the participants in the study (Akbiyik, 20I3).

Besides, another essential finding shows that students reported that Facebook helps them to maintain connections with people whom they cannot see them in their real life. This finding is in accordance with a case study on the impact of Facebook as a social networking site on youth generations carried out by Chowdhury et al., (2015) their study positive impacts asserted that Facebook allow teenagers as well as Facebook seekers to communicate with their friends. In addition, scholars can build relations with familiar and unfamiliar friends. Users can maintain their pervious and new bonding of friendship as well as other relations. Also, the finding of this study reveals more that Education Faculty's students feel fine when they share their opinions on Facebook. Through this, it can be inferred that students do not feel bad when they post or share their views on Facebook. This finding is in line with Nawafleh et al., (2012) that participants feel much more comfortable and free when share opinions and thoughts through Facebook more than direct interaction, and give priority to communicate with friends on Facebook over their social and career commitments. In addition, the findings illustrate that Facebook has positive effects on students' social life. This finding is in line with Akbiyik (2013) who conducted a study on college undergraduate students' social life, Turkey. The findings revealed that Facebook has impacts on learners' social life.

\section{Conclusion and Suggestions}

The findings of this study revealed that students spend nearly 30-60 minutes on the use of Facebook. Furthermore, students had the enthusiasm to have friends from their relatives in Facebook, and it helped students to maintain in relation with people who were far from them in their real life as well felt good when they share their opinions on the wall of Facebook. In addition, it had positive impacts on learners' social life. Likewise, as this study worked on the impacts of Facebook on students' social life at Mirwais Khan Nika Zabul Institute of Higher Education, Zabul, Afghanistan. As a result, the following suggestions are given for further studies to be conducted in this and other contexts: to investigate the current status of using Facebook, the purposes of using Facebook, the impacts of Facebook on students' academic life, learning, behavior, health, and on the academic performance of learners.

\section{Acknowledgments}

The researcher strongly acknowledges from all students who participated in this study.

\section{References}

Akbiyik, C. (2013). Effects of Social Networks on Social life of Undergraduate students. Middle Eastern \& African Journal of Educational Research, 4(6), 4-I0. 
Alhazmi, A. K., \& Rahman, A. A. (2013). Facebook in higher education: Students' use and perceptions. Advances in Information Sciences and Service Sciences, 5(I5), 32.

Ali, A., Iqbal, A., \& Iqbal, K. (2016). Effects of Social Media on Youth: A Case Study in the University of Sargodha. International Journal of Advanced Research, 4(II), 369-372.

Aliaga, M., \& Gunderson, B. (2002). Interactive statistics. Virginia. America: Pearson Education.

Altai Consulting for Interviews. (2017). Social Media in Afghanistan, Afghanistan.

Aygul, E. (2010). Facebook'ta Nefret Söyleminin Üretilmesi Ve Dolaşıma Sokulması, Yeni Medyada Nefret Söylemi, Tuğrul Çomu (Ed.), İstanbul.

Boateng, R., \& Amankwaa, A. (2016). The impact of social media on student academic life in higher education. Global Journal of Human-Social Science, I6(4), I-8.

Chowdhury, I. R., \& Saha, B. (2015). Impact of Facebook as a social networking site (SNS) on youth generations: A case study of Kolkata city. International Journal of Humanities and Social Science Invention, 4(6), 28-42.

Diraditsile, K., \& Gamakabadi, G. (2018). The effect of social media on student engagement and collaboration: The use of Facebook at the University of Botswana. Nonaka J. Learn. Teach, 9, 70-83.

Eke, H., Omekwu, C. \& Jennifer, N. (20I4). The use of social networking sites among the undergraduate student of the University of Nigeria, Nsukka. Library Philosophy and Practice, O_I.

Ellefsen, L. (20I6). An Investigation into Perceptions of Facebook-Use in Higher Education. International Journal of Higher Education, 5(I), I60-I72.

Ellison, N. B., Steinfield, C., \& Lampe, C. (2007). The benefits of Facebook “friends:” Social capital and college students' use of online social network sites. Journal of computer-mediated communication, I2(4), I I43-I I68.

Gafni, R., \& Deri, M. (2012). Costs and benefits of Facebook for undergraduate students. Interdisciplinary Journal of Information, Knowledge, and Management, 7(I), 45-6I.

Gomm, R., Hammersley, M., \& Foster, P. (2000). Case study and generalization. Case study method, 98-I I5.

Heiberger, G. \& Harper, R. (2008). Have you Facebooked Astin lately? Using technology to increase student involvement. New Directions for Student Services, I24.

Johnson, S. (2013). The Effect of Social Media for College Students Today. Available on http://sierrajfinalproj.weebly.com/uploads/2/5/2/I/2521758/iteration2_sierraj.pdf [Retrieved on January 2017]

Kirik, A., Arslan, A., Çetinkaya, A., \& Mehmet, G. Ü. L. (2015). A quantitative research on the level of social media addiction among young people in Turkey. International Journal of Sport Culture and Science, 3(3), I08-I22.

Kirkpatrick, D. (2010). The Facebook Effect: The Inside Story of the Company That is Connecting the World. New York: Simon \& Schuster.

Lenhart, A., \& Madden, M. (2007). Social networking websites and teens: An overview (pp. I-7). Washington, DC: Pew/Internet.

Madan, C. R., \& Kensinger, E. A. (2017). Test-retest reliability of brain morphology estimates. Brain informatics, 4(2), I07-I2I.

Mason, M. (2017). The use of the internet and social media by young people.

Mustafa, S. E., \& Hamzah, A. (20II). Online social networking: A new form of social interaction. International Journal of Social Science and Humanity, $I(2), 96$.

Nawafleh, S., Harfoush, O., Fakhouri, S., Obiedat, R., Rababah, O. (2012). Facebook Impact on Users Social Life. Journal of American Science, 8(12). 333-339.

O'Keeffe, G. S., \& Clark-Pearson, K. (20II). The impact of social media on children, adolescents, and families. Pediatrics, I27(4), 800-804.

Orr, E. S., Sisic, M., Ross, C., Simmering, M. G., Arseneault, J. M., \& Orr, R. R. (2009). The influence of shyness on the use of Facebook in an undergraduate sample. CyberPsychology \& Behavior, I2(3), 337-340.

Paul, A. (2017). Impact of Facebook on urban youth: A study on Kolkata Metropolitan. International Journal of Research in Social Sciences, 7(7), 453-463.

Pempek, T. A., Yermolayeva, Y. A., \& Calvert, S. L. (2009). College students' social networking experiences on Facebook. Journal of applied developmental psychology, 30(3), 227-238.

Salvation, M., \& Adzharuddin, N. A. (2014). The influence of social network sites (SNS) upon the academic performance of Malaysian students. International Journal of Humanities and Social Sciences, 4(I0), I3I-I37.

Sangwaan, R. (2019). Use of Social Media in Education: Positive and Negative Impact on The Students. International Journal on Transformations of Media, Journalism \& Mass Communication, 4(2).

Schneider, N. (2010). Facebook, Other Social Network Sites Could Lead to Lower Grades for Students.

Selwyn, N. (2007). Screw Blackboard do it on Facebook!': an investigation of students' educational use of Facebook. Ponencia. En: Poke.

Sheldon, P. (2008). Student favorite: Facebook and motives for its use. Southwestern Mass Communication Journal, 23(2). 
Stern, L. A., \& Taylor, K. (2007). Social networking on Facebook. Journal of the Communication, Speech \& Theatre Association of North Dakota, 20(2007), 9-20.

Tang-Mui, J., \& Teng, C. E. (2017). Impacts of social media (Facebook) on human communication and relationships: A view on behavioral change and social unity. International Journal of Knowledge Content Development \& Technology, 7(4), 27.

Valenzuela, S., Park, N., \& Kee, K. F. (2009). Is there social capital in a social network site?: Facebook use and college students' life satisfaction, trust, and participation. Journal of computer-mediated communication, I4(4), 875-901.

Wang, Q., Chen, W., \& Liang, Y. (20I I). The effects of social media on college students.

Yin, R. K. (1994). Case Study Research Design and Methods: Applied Social Research and Methods Series. Second ed. Thousand Oaks, CA: Sage Publications Inc.

\section{Copyrights}

Copyright for this article is retained by the author(s), with first publication rights granted to the journal. This is an open-access article distributed under the terms and conditions of the Creative Commons Attribution license (http://creativecommons.org/licenses/by/4.0/). 